\title{
Unconventional Monetary Policy and International Interest Rate Spillovers
}

\author{
By Karlye Dilts Stedman
}

A fter the 2008 global financial crisis, advanced economies turned to unconventional monetary policies, such as forward guidance and large-scale asset purchases, to provide additional monetary stimulus while short-term interest rates were constrained by their effective lower bound. However, the speed of economic recovery differed markedly among these economies, leading to increasingly divergent monetary conditions heading into 2020. While the euro area and Japan increased their unconventional monetary stimulus through 2020, the United States and the United Kingdom began raising short-term interest rates in December 2015 and November 2017, respectively.

Differences in the timing and intensity of unconventional monetary policies across central banks generate potentially unique international "spillover effects." As some central banks normalize policy by moving policy rates off their effective lower bound, domestic short-term interest rates rise. But this increase in short-term rates may not translate into higher longer-term rates if unconventional monetary policies in other countries spill over internationally, exerting downward pressure on rates. In this way, expansionary spillovers from other central banks may have undermined policy tightening in the United States (as well as the United Kingdom). However, while abundant research documents

Karlye Dilts Stedman is an economist at the Federal Reserve Bank of Kansas City. This article is on the bank's website at www.KansasCityFed.org 
spillovers from the Federal Reserve's monetary policy to other economies, the effects of other central banks' policies on the United States have received limited study despite an evolving policy landscape.

In this article, I assess whether monetary policies from the European Central Bank (ECB), the Bank of Japan, and the Bank of England affect U.S. borrowing costs differentially at and away from the effective lower bound from 2004 to 2017. I find evidence of spillovers from each of these central banks to the United States as well as evidence that these spillovers increased during the Federal Reserve's asynchronous withdrawal from unconventional monetary policy. My results imply that in the absence of international spillovers, long-term yields in the United States would have been higher than those observed at the end of 2017. More generally, my results contradict an implicit assumption in prior research that the United States generates monetary policy spillovers without also receiving them.

Section I discusses the mechanisms of monetary policy at and away from the effective lower bound to clarify why policy might spill over from one country to another. Section II discusses how I measure monetary policy and its associated spillovers. Section III documents increased spillovers from foreign central banks to the United States during and after the global financial crisis.

\section{Monetary Policy at and away from the Effective Lower Bound}

In theory, both conventional and unconventional monetary policy in one country can affect other economies. Conventional expansionary monetary policy lowers short-term borrowing costs by decreasing the interest rates banks charge one another for overnight loans, which banks in turn pass on to the broader economy. ${ }^{1}$ This accommodative policy could generate expansionary or contractionary spillovers to other countries. On the one hand, by boosting real activity in the domestic economy, conventional channels of monetary policy may also increase the economic activity of international trading partners by boosting their net exports (Brainard 2017). On the other hand, if expansionary policy leads to local currency depreciation, trading partners may see a decrease in their net exports. 
More directly, conventional monetary policy in one country can influence financial conditions in others by raising or lowering the cost of capital for firms and individuals that lend funds abroad (see, for example, Cetorelli and Goldberg 2012; Morais and others 2019; Baskaya and others 2017; and Miranda-Agrippino, Nenova, and Rey 2020). Conventional monetary policy can also affect foreign economies through central bank communications, as when a central bank reveals information about global economic news that foreign investors expect to affect them at home (Kose, Otrok, and Whiteman 2003; Baxter and Kouparitsas 2005).

Unconventional monetary policies, such as those central banks have undertaken in recent years, have the potential for additional spillover effects to foreign economies. After the global financial crisis, most central banks lowered short-term interest rates to near zero, limiting their ability to stimulate growth through additional rate cuts-a constraint commonly referred to as the "effective lower bound." To provide additional monetary accommodation in the face of this constraint, central banks pursued large-scale asset purchases (LSAPs) which, coupled with forward guidance regarding the future path of policy, aim specifically to lower long-term interest rates by managing market expectations and reducing term premiums. ${ }^{2}$ Most LSAPs have targeted government bonds to lower their yields, with the ultimate goal of lowering borrowing costs for households and businesses. ${ }^{3}$ Lower government bond yields give investors incentive to replace government bonds with as close a substitute as possible. Many investors will shift to another domestic asset, lowering the yield on that asset and thereby decreasing borrowing costs for the firms that issue it. However, investors may also shift to foreign bonds, generating unique international spillovers. When domestic investors shift to foreign bonds in response to a decrease in domestic bond yields, they decrease borrowing costs abroad.

Given the potential for international spillovers from LSAPs, central banks' asynchronous withdrawal from LSAPs may have created additional headwinds for the Federal Reserve in normalizing policy. In 2013, the Federal Reserve began to taper its asset purchases as a first step in the policy normalization process - in other words, the unwinding of unconventional policies and return to conventional monetary policy through short-term interest rate adjustments. ${ }^{4}$ Starting in 
December 2015, the Federal Reserve entered a normalization period in which it slowly raised rates. However, the ECB and the Bank of Japan did not follow suit, and as of the end of the sample in late 2017, neither bank had yet to begin policy normalization. The Bank of England took an approach between these poles, halting asset purchases in 2013 but keeping the interest rate near zero until late 2017. Ongoing policy accommodation from the ECB, Bank of Japan, and to a lesser extent, the Bank of England may have dampened long-term interest rates in the United States in particular as its monetary policy diverged from that of the other three largest advanced economies.

\section{Measuring Monetary Policy Spillovers}

Measuring the effect of monetary policy can be challenging. To the extent households and businesses observe the state of the economy and know the mandate that guides a central bank's policy response, they may anticipate future policy changes and adjust their consumption and production decisions accordingly in advance of the actual policy change. Thus, only the announcement of unexpected changes to monetary policy —or monetary policy "shocks" — should have an observable effect on real and financial variables. At the time of the announcement, market participants update their information about the policy stance, which is immediately reflected in the prices of affected securities.

To extract monetary policy shocks for each central bank, I follow Kuttner (2001) and Gürkaynak, Sack, and Swanson (2005), among others, who measure shocks using the change in the price of a chosen asset from before a central bank announcement to shortly after. The assumption underlying this approach is that, on average, only new information about monetary policy affects the asset's price in this window. In other words, if markets that are closely linked to monetary policy decisions change immediately after a monetary policy announcement, the asset's price is assumed to have changed because of monetary policy itself.

I focus on monetary policy shocks from 2004 to 2017 from the Bank of England, Bank of Japan, and ECB for two reasons. First, they are key advanced-economy central banks (apart from the Federal Reserve); because of the size of their balance sheets, they are the most likely to generate spillovers to the United States. Second, U.S. Treasuries may be considered a close substitute for sovereign bonds issued by 
the United Kingdom, Japan, or euro area governments, which makes them more likely to have propagated spillovers from LSAPs.

To extract the magnitude of a monetary policy shock that can be compared across all four central banks, I use assets that are not only linked to monetary policy outcomes, but also commonly traded. Each economy has an active interbank lending market with its own threemonth interbank offered rate, the benchmark interest rate at which banks make short-term loans to one another. This rate is strongly influenced by current policy and expectations of future policy rates. Futures contracts based on this rate and settling two years in the future are all traded continuously throughout the 2004-17 sample period and continue to vary even when short-term interest rates remain near zero. ${ }^{5}$ I use the daily change in the yields implied by these overnight interbank interest rate futures prices as my measure of the surprise element contained in announcements by each respective central bank. For ease of interpretation and comparability across central banks, I normalize monetary policy shocks to a one-standard-deviation reduction in the two-year-ahead futures rate, in basis points.

Each central bank publishes policy committee announcement and meeting dates on their respective web sites. The majority of included central bank announcement dates in the sample correspond to regularly scheduled meetings. However, I also include some unscheduled announcement dates due to their importance during the early months of the global financial crisis. While most announcements reflect no change in policy (or a change that is widely anticipated) and cause little reaction in financial markets, some announcements are unexpected. These unexpected announcements cause identifiable asset price movements linked to the effects of policy shocks on financial markets.

To find the effect of monetary policy on borrowing costs, I use a well-established statistical model to measure the effect of monetary policy shocks on the yields on sovereign securities in each of the sample countries at short (one to three year), medium (five to seven year), and long (10 year) maturities from 2004 to 2017 (full model details are available in Dilts Stedman [2019]). ${ }^{6}$

Because central bank policy actions changed dramatically before, during, and after the 2008 financial crisis, I break the full sample into three subsamples based on significant changes to the Federal Reserve's 
LSAP policies. I focus on LSAPs because they represent a key unconventional tool used by all four central banks. I define the subsamples based on U.S. dates in particular because the Federal Reserve both initiated and ended LSAPs first among central banks in the post-2007 period. Table 1 defines the three subsamples, which are the same for all central banks for ease of comparison. The first, from September 4, 2004, to September 14, 2008, captures the pre-crisis period before the failure of Lehman Brothers set off market volatility that resulted in the first round of the Federal Reserve's LSAPs. During the pre-crisis period, central banks were not only all engaged in short-term interest rate policy, but were also all in a tightening cycle. The second period comprises the second and third rounds of the Federal Reserve's LSAPs in response to the global financial crisis and the European debt crisis, along with the Maturity Extension Program, from November 25, 2008, to May 21,2013 . In this period, all four central banks lowered policy rates to near zero and began pursuing monetary policy loosening through various means that fall under the rubric of unconventional monetary policy. ${ }^{7}$ The third and final subsample begins on May 22, 2013, with the announcement that the Federal Reserve would soon begin to taper its asset purchases and thereby begin the process of monetary policy normalization, and ends with the last date in the sample, December 15, 2017. In this subsample, the Federal Reserve announced it would begin to remove some of its monetary policy accommodation and begin a return to conventional monetary policy, thereby altering market expectations. In contrast, the other central banks either maintained their existing policy stance (Bank of England) or increased their degree of monetary policy accommodation with further asset purchases and negative interest rates (ECB and Bank of Japan).

\section{Documenting the Evolution of International Spillovers}

To visualize the differences in potential spillovers across maturities, I plot the effect of one-standard-deviation monetary policy shocks from the Bank of Japan, ECB, and Bank of England on one, three, five, seven, and 10-year U.S. Treasury yields. For comparison, Chart 1 plots the estimates from the full sample with no regime changes alongside estimates of the domestic effects of Federal Reserve actions. The full 


\section{Table 1}

Regime Changes in U.S. Monetary Policy, 2004-17

\begin{tabular}{l|l}
\hline \hline Date & Subsample break dates \\
\hline Sep. 15, 2008 & $\begin{array}{l}\text { End of the pre-crisis period: The collapse of Lehman Brothers ignites turmoil in financial } \\
\text { markets that elicits monetary policy easing in advanced economies. }\end{array}$ \\
Nov. 25, 2008 & $\begin{array}{l}\text { Initial QE: The Federal Reserve announces its first quantitative easing program. } \\
\text { May 22, 2013 }\end{array}$ \\
\hline
\end{tabular}

\section{Chart 1}

The Effect of U.S. and Foreign Monetary Policy Shocks on U.S. Yields (Full Sample)

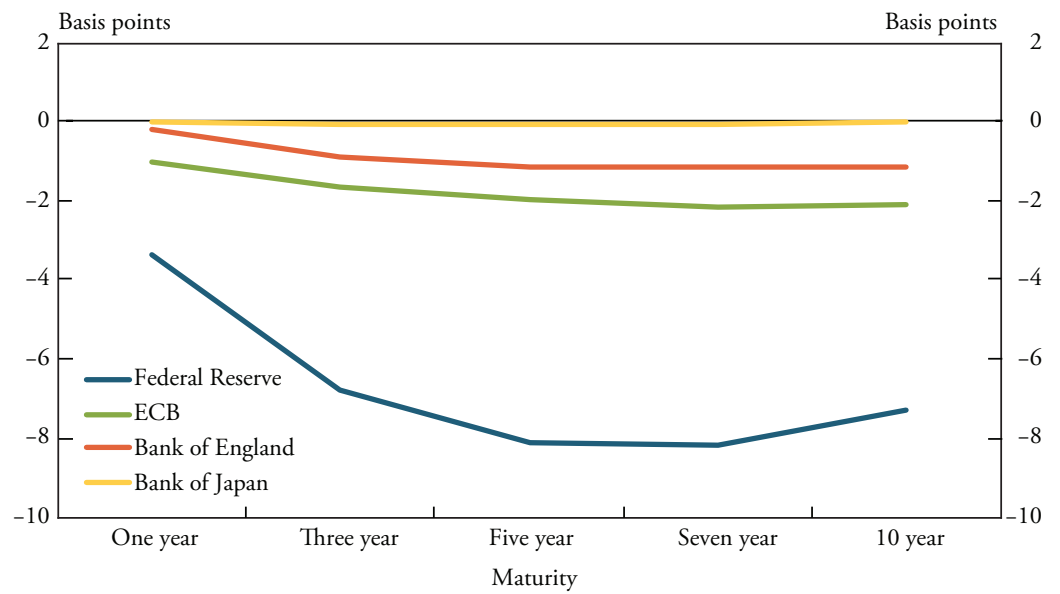

Sources: Board of Governors of the Federal Reserve System, ECB, Bank of England, Bank of Japan, and author's calculations.

sample results suggest significant effects of Federal Reserve policy shocks on U.S. Treasury rates but minimal spillovers from other central bank policy shocks to U.S. Treasuries, with little difference across maturities.

However, the full sample obfuscates important subsample patterns. Charts $2-4$ show that the effect of monetary policy shocks by maturity differs substantially by subsample, underscoring the importance of reevaluating spillovers as conditions change. In particular, Chart 2 shows that spillovers from the ECB to the United States increased substantially during the global financial crisis and increased even further when the United States began withdrawing from unconventional monetary policy. In the initial LSAP period (green line), a monetary policy shock from the ECB lowered U.S. yields on five-year notes by 2.2 basis points; 


\section{Chart 2}

The Effect of ECB Monetary Policy Shocks on U.S. Yields

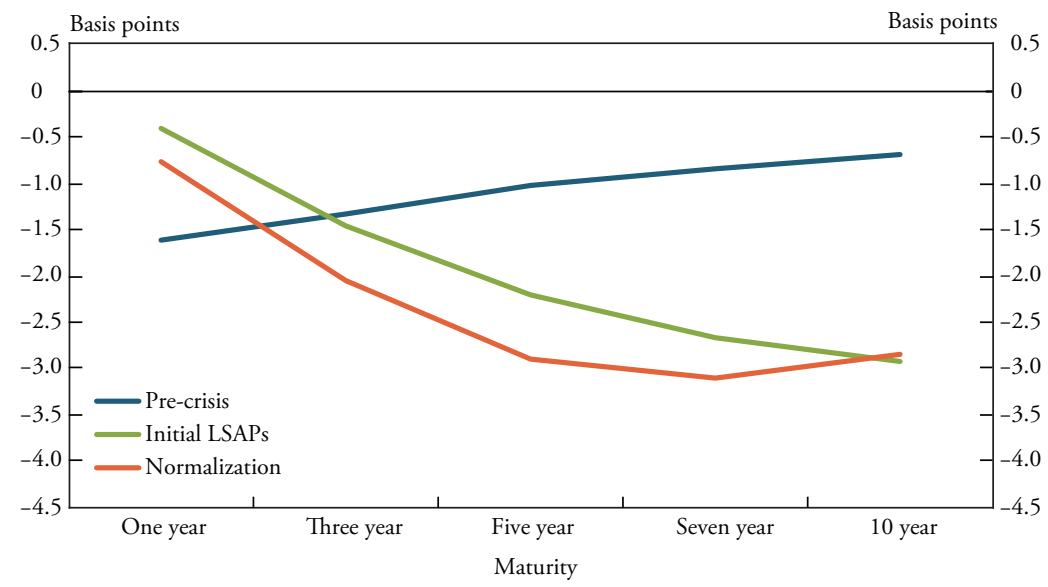

Sources: Board of Governors of the Federal Reserve System, ECB, and author's calculations.

\section{Chart 3}

The Effect of Bank of England Monetary Policy Shocks on U.S. Yields

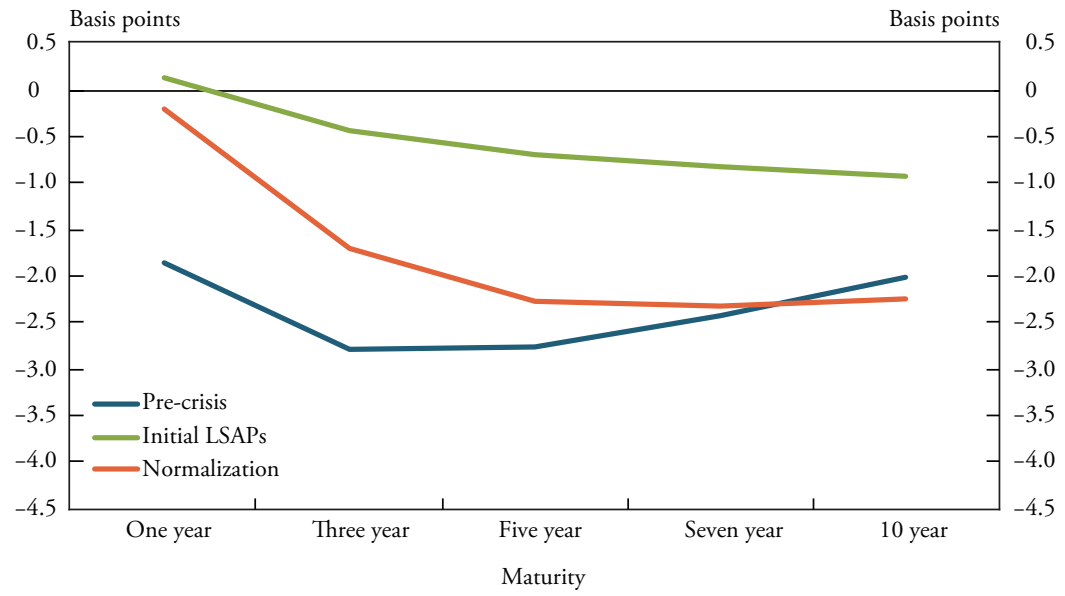

Sources: Board of Governors of the Federal Reserve System, Bank of England, and author's calculations. 


\section{Chart 4}

The Effect of Bank of Japan Monetary Policy Shocks on U.S. Yields

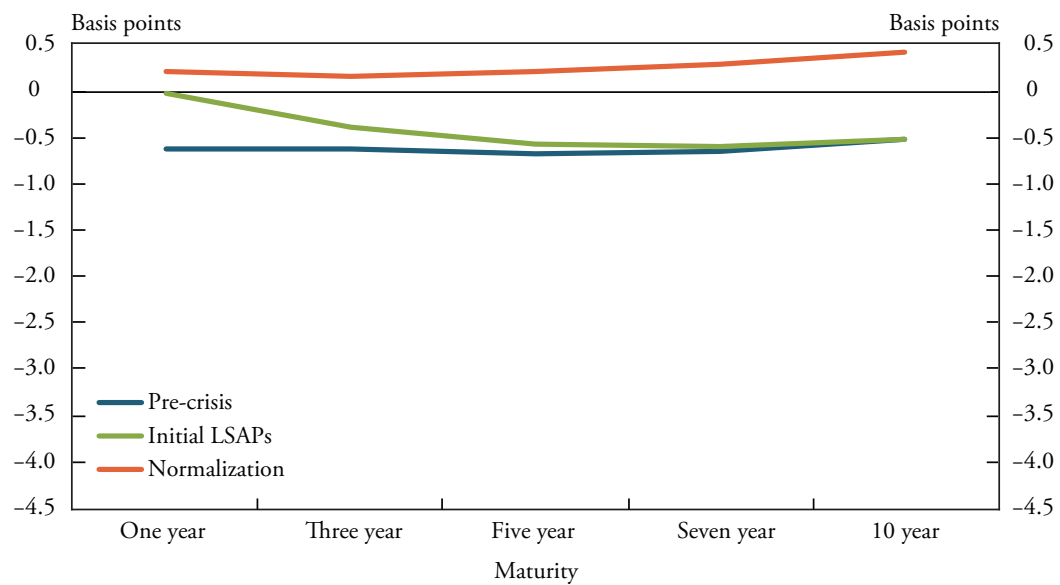

Sources: Board of Governors of the Federal Reserve System, Bank of Japan, and author's calculations.

in the normalization period (orange line), the same-size shock lowered yields by 2.91 basis points, corresponding to an increase in spillovers of about 33 percent.

One explanation for the greater spillovers in the normalization period relative to the initial LSAP period is that this period coincides with the ECB's first purchases of government securities of member countries in a form analogous to the other central banks in the sample. ${ }^{8}$ However, Chart 3 shows that the Bank of England also propagated greater spillovers in the normalization period. In particular, Chart 3 shows that monetary policy shocks from the Bank of England generated substantial spillovers to the United States in the pre-crisis period, which ebbed in the initial LSAP period but returned to pre-crisis levels during Federal Reserve policy normalization. ${ }^{9}$

Adding up the spillovers in Charts 2 and 3 shows that during the Federal Reserve's policy normalization period, monetary policy shocks from the Bank of England and ECB had a combined effect on 10year U.S. yields that nearly eclipsed the 6.1 basis point effect of the Federal Reserve's own policy tightening $(2.2+2.8=5.0)$. Indeed, in Dilts Stedman (2019), I find that the combined effect overshadows the domestic effect in estimates that separate out the period of lift-off from the effective lower bound from the tapering announcement two 


\section{Chart 5}

\section{Counterfactual 10-Year Treasury Yields}

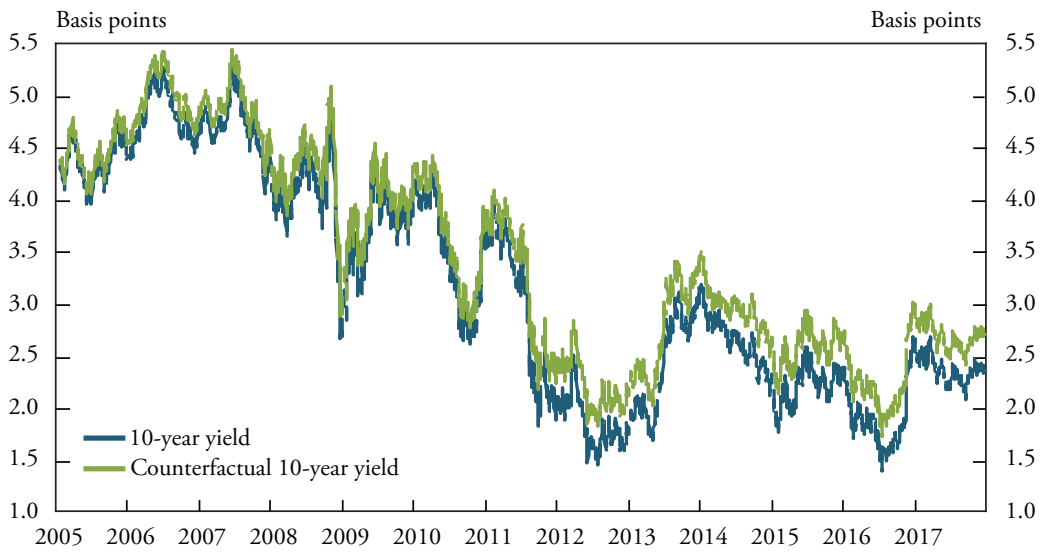

Sources: Board of Governors of the Federal Reserve System and author's calculations.

years earlier. Thus, spillovers from Bank of England and ECB monetary policies more than offset the effect of Federal Reserve policy normalization on U.S. longer-term rates, neutralizing the transmission of domestic monetary policy to long-term interest rates.

In contrast, Chart 4 shows that spillovers from the Bank of Japan were small across subsamples and maturities, reflecting low co-movement with other advanced economies in general. This low historical co-movement suggests that U.S. and Japanese sovereign bonds may not be close substitutes.

In summary, in the pre-crisis period, spillovers to the United States were generally small across maturities and more prevalent for Treasuries with shorter maturities. In the initial LSAP period, spillovers to the United States strengthened from the ECB but weakened from the Bank of England. And in the period of U.S. monetary policy normalization, characterized by the highest degree of policy asynchronicity, spillovers increased from both the ECB and Bank of England. Together, these results suggest that asynchronous normalization was indeed, on net, consistent with lower long-term yields than would otherwise have prevailed from tightening domestic policy.

To illustrate the cumulative effect of spillovers, Chart 5 plots actual yields for 10-year Treasury securities from 2004 through the end of the sample in 2017 (blue line) alongside a counterfactual (green line) 
depicting what yields would have been in the absence of international spillovers. My results suggest that without international spillovers, the 10 -year Treasury yield would have been an average of 35 basis points higher over the period of normalization from 2013 to 2017.

\section{Conclusion}

In 2020, central banks across the world have again lowered shortterm interest rates to the effective lower bound in response to the COVID-19 pandemic. With the lessons from the global financial crisis in hand, central banks would do well to acknowledge the influence of spillovers on sovereign bond yields-including spillovers from other central banks to the United States, which have received much less attention in the past. While the United States receives much attention for its influence on the global financial cycle, I find evidence of surprisingly strong spillovers to the United States from the United Kingdom and the euro area at the effective lower bound, particularly during the period of asynchronous monetary policy normalization. These results highlight the unique international features of monetary policy at the effective lower bound and suggest that failure to consider the differential effects of different policy environments may lead to the mismeasurement of spillovers.

The mechanisms of unconventional monetary policy that distinguish it from conventional monetary policy present unique challenges to the withdrawal of monetary stimulus, particularly in the presence of spillovers. Domestic long-term interest rates may respond less to policy rate increases when other countries are simultaneously engaging in LSAPs. Thus, without international spillovers, long-term yields in the United States would have been higher in the policy normalization period.

These spillovers have implications for the conduct of foreign monetary policy as well. In the absence of international spillovers, the ECB and Bank of England's LSAPs would have been more effective in lowering long-term private borrowing costs in the euro area and the United Kingdom, respectively, after the 2008 financial crisis. Without leakages to U.S. Treasuries, investors in the United Kingdom and euro area would have more fully allocated their funds to domestic private assets, as intended. 


\section{Endnotes}

${ }^{1}$ Since lifting off the effective lower bound in 2015, the Federal Reserve has targeted the federal funds rate by setting the interest rate on bank reserves.

${ }^{2}$ The longer the maturity on a bond (or any debt), the more expensive it typically is to borrow. Longer-term interest rates tend to be higher than shortterm interest rates because lenders' expectations over future growth, policy rates, and inflation are subject to the risk that the bond they purchase may become less valuable relative to future offered market rates. The return on long-term bonds over and above the amount expected by reinvesting short-term securities is called the term premium, which increases with the bond's maturity (Bernanke 2013).

${ }^{3}$ Central banks have also engaged in LSAPs to achieve other goals. For example, in its initial responses to the global financial crisis, the Federal Reserve first purchased assets in markets experiencing distress, such as mortgage-backed securities, to lower their yields. By standing willing to purchase such assets, the Federal Reserve decreases the risk that they cannot be sold.

${ }^{4}$ When the Federal Reserve and, to a lesser extent, the Bank of England began to unwind unconventional monetary policy, they focused first on tapering asset purchases. The Federal Reserve took the additional step of raising interest rates before decreasing the size of its balance sheet and is the only advanced central bank in this study to have reached this step of normalization before the economic crisis in 2020. Thus, the Federal Reserve's approach to normalization raised short-term interest rates before fully unwinding the long-duration assets on its balance sheet.

${ }^{5}$ These are the three-month Euro Interbank Offered Rate (EURIBOR), Sterling London Interbank Offered Rate (Sterling LIBOR), Eurodollar, and Euroyen Tokyo Interbank Offered Rate (Euroyen TIBOR).

${ }^{6}$ To account for the possibility of other economic or financial news being released on the same day as a monetary policy announcement, I include in my model a measure of news surprises from Citigroup (the Citigroup Economic Surprise Index or CESI) for each of the sample countries to strengthen the assumption that the daily effect measured is from monetary policy. These results can be accessed in Dilts Stedman (2019).

${ }^{7}$ In practice, the effective lower bound has differed across countries. While the Federal Reserve and Bank of England lowered (and kept) their interest rates near, but above, zero, the ECB and Bank of Japan have pursued negative interest rate policies.

${ }^{8}$ I follow Bernanke (2009) and others and define LSAPs as a central bank balance sheet expansion focused on the mix of loans and securities that the central bank holds, with explicit consideration on the effect this composition of assets affects credit conditions. This definition distinguishes the experience of the ECB from the Federal Reserve, the Bank of England, and the Bank of Japan. In contrast to these other central banks, the ECB's balance sheet expansion during 
its early crisis response mainly reflects its increased intermediation role and the growth of its lending to banks, which play a crucial part in financing the euro area's private sector. While the other central banks orchestrated the growth of their balance sheets as part of their LSAPs, in the case of the ECB, the requirements of commercial banks and their need for refinancing drove balance sheet expansion. The contraction of the ECB's balance sheet that began in 2012 reflected the banks' declining need for liquidity following the reduction in financial fragmentation in the euro area.

${ }^{9}$ In Dilts Stedman (2019), I find that after adding an estimate for the size of spillovers when the Federal Reserve began to lift off from the zero lower bound, spillovers from the Bank of England increased even further, surpassing their precrisis effect. 


\section{References}

Baskaya, Yusuf Soner, Julian di Giovanni, Şebnem Kalemli-Özcan, José-Luis Peydró, and Mehmet Fatih Ulu. 2017. "Capital Flows and the International Credit Channel.” Journal of International Economics, vol. 108, no. S1, pp. S15-S22. Available at https://doi.org/10.1016/j.jinteco.2016.12.003

Baxter, Marianne, and Michael A. Kouparitsas. 2005. "Determinants of Business Cycle Comovement: A Robust Analysis.” Journal of Monetary Economics, vol. 52, no. 1, pp. 113-157. Available at https://doi.org/10.3386/w10725

Bernanke, Ben S. 2013. "Communication and Monetary Policy." Speech at the National Economists Club Annual Dinner, Washington, DC, November 19.

Brainard, Lael. 2017. "Cross-Border Spillovers of Balance Sheet Normalization." Speech at "Normalizing Central Banks' Balance Sheets: What Is the New Normal," Columbia University School of International and Public Affairs and Federal Reserve Bank of New York, July 11.

Cetorelli, Nicola, and Linda S. Goldberg. 2012. "Banking Globalization and Monetary Transmission.” Journal of Finance, vol. 67, no. 5, pp. 1811-1843. Available at https://doi.org/10.1111/j.1540-6261.2012.01773.x

Dilts Stedman, Karlye. 2019. "Unconventional Monetary Policy, (A)Synchronicity and the Yield Curve." Federal Reserve Bank of Kansas City, Research Working Paper no. 19-09, November. Available at https://doi.org/10.18651/ RWP2019-09

Gürkaynak, Refet S., Brian Sack, and Eric Swanson. 2005. "The Sensitivity of Long-Term Interest Rates to Economic News: Evidence and Implications for Macroeconomic Models." American Economic Review, vol. 95, no. 1, pp. 425-436. Available at https://doi.org/10.1257/0002828053828446

Kose, M. Ayhan, Christopher Otrok, and Charles H. Whiteman. 2003. "International Business Cycles: World, Region, and Country-Specific Factors." American Economic Review, vol. 93, no. 4, pp. 1216-1239. Available at https://doi. org/10.1257/000282803769206278

Kuttner, Kenneth N., 2001. "Monetary Policy Surprises and Interest Rates: Evidence from the Fed Funds Futures Market." Journal of Monetary Economics, vol. 47, no. 3, pp. 523-544. Available at https://doi.org/10.1016/S03043932(01)00055-1

Miranda-Agrippino, Silvia, Tsvetelina Nenova, and Hélene Rey. 2020. "Global Footprints of Monetary Policies.” Centre for Macroeconomics Discussion Paper Series, no. 2020-04.

Morais, Bernardo, José-Luis Peydró, Jessica Roldán-Peña, and Claudia Ruiz-Ortega. 2019. "The International Bank Lending Channel of Monetary Policy Rates and QE: Credit Supply, Reach-for-Yield, and Real Effects." Journal of Finance, vol. 74, no. 1, pp. 55-90. Available at https://doi.org/10.1111/ jofi. 12735 